\title{
O FENÓMENO DA CONSCIÊNCIA NO DESENHO: NA PROCURA DA LIBERDADE NA EXPERIÊNCIA DO UNIVERSAL ${ }^{1}$
}

\author{
Luís Filipe Salgado Pereira Rodrigues
}

Resumo: Pretende-se com esta reflexão explicar de que forma o desenho poderá proporcionar uma maior consciência do eu e do não-eu, e como isso permite progressivamente proporcionar ao sujeito uma maior liberdade tanto de ação mental e física como maior liberdade espiritual. O artigo está dividido em duas partes: I Enquadramento conceptual em António Damásio; e II Expansão da liberdade a partir do alargamento da consciência no contexto do ato de desenhar.

Palavras-chave: desenho, consciência, liberdade.

The phenomenon of consciousness in the drawing: In pursuit of freedom in the experience of the universal (Abstract): It is intended with this reflection to explain how the drawing may provide a greater awareness of self and non-self, and how it enables the subject to provide progressively greater freedom of action both mentally and physically and greater spiritual freedom. The article is divided into two parts: I - Conceptual framework of the phenomenon of consciousness in António Damásio, and II - The expansion of freedom from the enlargement of consciousness in the context of the act of drawing.

Keywords: drawing, consciousness, freedom.

\footnotetext{
${ }^{1}$ Nota: Artigo revisto e aceite para publicação sob a responsabilidade da anterior direcção da revista Psicologia.
} 


\section{O ato de desenhar no contexto conceptual do fenómeno da consciência em António Damásio}

\section{O sentido de si e o processo de consciencialização através de imagens}

António Damásio (2004) refere que no nosso organismo o cérebro produz padrões neurais nos seus circuitos de células nervosas, que por sua vez são transformados em padrões mentais explícitos. A estes padrões mentais António Damásio (2004) chama imagens - as imagens dos objetos. Os padrões mentais - as imagens - são o resultado de um sistema sensorial qualquer e podem, também, representar: os aspetos das caraterísticas físicas do objeto; ou o gosto ou aversão que se pode nutrir por um objeto; os planos que se podem formular para esse objeto; a teia de relações desse objeto com outros objetos (Damásio, 2004). Essas imagens são, por nossas palavras, a representação de algo que ativa a nossa ação individual no sentido de mantermos a nossa vitalidade no contexto ambiental (no sentido lato) em que nos inserimos; são, na realidade, a matéria com que agimos contra ou a favor da nossa liberdade.

Esses objetos são os causadores do sentido de $s i^{2}$, sempre que sejam sujeitos ao processo de conhecer cujo ator é o si (o eu). Sendo que para nós o sentido de si é a nossa oscilante conquista de um sentimento de liberdade interna, o que se prende com o reconhecimento de que somos uma identidade diferente das outras (deixamos de estar presos à imagem dos outros; criamos a nossa própria imagem). Mas esse processo de conhecimento só se efetiva quando o ser (o organismo, no sentido lato) sofre as modificações que são criadas através de relações e reações (cujo efeito é a construção e reconstrução da imagem genuína de si). Desta permanente ação-reação, resultam avanços e recuos no referido sentimento de liberdade (ora nos refugiamos na projeção do Outro, ora reconquistamos o nosso próprio poder de ação). É neste plano de gestão das relações e reações que encontramos o ser como proprietário das imagens, de que é espetador, entendedor, conhecedor, pensador e possível ator (Damásio, 2004), e é com base nestas que o ser constrói e reconstrói a sua liberdade, na medida em que as imagens (no sentido lato) sejam "manipuladas" pelo eu e não o contrário.

2 "O nosso sentido do si é um estado do organismo, o resultado de certos componentes funcionarem de uma maneira e interagirem de um certo modo, dentro de certos parâmetros. É também uma construção, um esquema vulnerável de operações integradas cuja consequência é criar a representação mental e um ser vivo individual.” (Damásio, 2004: 174) 
As imagens são a representação da modificação que o objeto exerce sobre o organismo; são o vestígio interno da imagem externa; são a informação que pode ser utilizada de uma forma tácita quando acontece inconscientemente, ou de uma forma manifesta quando acontece de uma forma consciente, ou de uma forma estruturante quando deliberadamente se desenvolve a consciência para além do aqui e agora. A modificação de que somos alvo é, na realidade, uma abertura na espiral da consciência e constitui, portanto, uma potenciação da expansão da nossa liberdade interna. Mas a imagem, retomando o nosso raciocínio, pode ser acompanhada por uma emoção negativa, de tal forma que esta assume o papel de ação, não permitindo ação ao eu e, assim, exercendo um contrapoder sobre este. Portanto, a manipulação do eu pela imagem, acontece, não pela ação desta, mas pela contra-ação exercida pela emoção. Assim, quando o organismo não sofre modificações, não se processa a representação da imagem (que contribui para a libertação), em vez disso, uma imagem arqueológica recoloca-se, gerando uma retroação em vez de uma pro-ação. Daí que a emoção alapada a uma imagem tenha o poder de manipulação do eu, isto é, do impedimento da sua ação de liberdade.

A emoção tem um papel basilar no processo de consciência, e este passa, segundo A. Damásio (2004), por vários níveis do si - o proto-si, o si nuclear, o si alargado e o si autobiográfico -, não dispensando o processo de conhecimento (o estar ciente de que existe determinada informação sobre). O autor diz-nos que quando sentimos o que acontece no momento em que ouvimos, vemos ou tocamos, a consciência começa o seu processo. $\mathrm{Ou}$ seja, estamos sempre a sentir. Portanto, quer haja uma emoção retardadora, quer haja uma emoção que provoque a pro-ação, a consciência é permanente, pois o nosso organismo está em permanente contato com uma incalculável variedade de "objetos" que lhe provocam o sentimento.

Sentir é para nós, de facto, um sinal de liberdade, pois é através dele que experimentamos o mundo. Na perspetiva de A. Damásio (2004), nesta experiência de consciência, numa primeira etapa, os dispositivos de representação do organismo geram um tipo específico de conhecimento sem palavras, de que o organismo foi modificado por um objeto (Damásio, 2004). A forma mais simples do que acontece nesta etapa é o sentimento ${ }^{3}$, que é aquele que nós temos individualmente, que nos permite dizer que as imagens são nossas e que nos permite afirmar que ouvimos, vemos ou tocamos, numa palavra, que nos proporciona a capacidade de ter as próprias sensações, aquando da relação com um objeto (Damásio, 2004). Esta possibilidade é aquela que dá a especial liberdade de ser ao Homem: a de experimentar o Mundo.

3 “O sentimento, entendido na perspectiva biológica, tem como substrato um conjunto de padrões neurais que resultam de modificações relacionadas com o estado corporal e modificações relacionadas com o estado cognitivo.” (Damásio, 2004: 321) 
Porém, como já foi mencionado, a consciência evolui no sentido da aquisição de um conhecimento que corresponda ao facto de que o organismo foi modificado por um objeto. Assim, após o sentimento de que tivemos uma determinada sensação, após sentirmos que o organismo foi modificado, criam-se condições para produção de inferências e interpretações que tomam a forma de sentimento de conhecer (Damásio, 2004). Na relação do indivíduo com o objeto, criam-se condições para receber e gerar novas informações, mas em ambos os casos existe algo que não é verbal que é o sentimento, aquela sensação que indica que o nosso organismo está em contato com nova informação; só depois se pode gerar uma informação estruturada passível de se traduzir pela linguagem.

$\mathrm{O}$ indivíduo caminha para a liberdade, não quando se prende à procura da verbalização da informação interna relativa ao(s) sentimento(s), mas quando aceita a nova informação externa para gerar nova informação interna. É aqui que se compõe a dialéctica subjetivo-objetivo, que propulsiona o fenómeno de expansão da consciência e o fenómeno de libertação. Sendo que, em termos absolutos, a objetivação é o que nos permite complexificar a compreensão do Mundo, pelo que poderíamos inferir que a grande liberdade implica um amplo domínio sobre a capacidade de verbalizar.

Este fenómeno de consciência poderá proporcionar-se na atividade do desenho, ao nível do encontro do sentido de si, como resultado do fenómeno de interação de um conjunto de elementos, pois, como nos diz Ana Leonor Rodrigues, "em todo o processo do desenho, a troca entre a identidade e intenções do autor, e as características próprias dos elementos e materiais utilizados, bem como dos códigos escolhidos para o fazer, constrói um sistema fenomenológico complexo e indivisível cujo sentido existe indissociável dessa integridade" (Rodrigues, 2000: 14).Ora, o encontro da integridade e do sentido de si (o único e o idiossincrático) resulta, precisamente, da interação do subjetivo-objetivo, em que o indivíduo gera maior informação interna imanente às suas características un(ic)as, que equivocamente poderiam ser as informações pessoais sobre as informações externas, mas que são na realidade a consciência mais universal do sujeito interno através do seu contato com o mundo externo. O subjetivo vale para o sujeito enquanto sentimento de seus sentimentos, contudo requer-se que o sujeito utilize o sentimento de seus sentimentos para se transpor para um campo objetivo em que, através da informação externa, percebe os sentimentos do campo subjetivo do Outro. Daí a importância do processo de intersubjetividade para o fenómeno da consciência do eu. O desenho funciona, nesta perspetiva, como objeto de inter e intra-comunicação; por muito subjetivo que seja o desenho é inevitavelmente o resultado de uma objetivação, pois é a ideia tornada objeto (bidimensional). 


\section{Das emoções ao conhecimento dos sentimentos das emoções no contexto da consciência}

De facto, a vida é conduzida, de acordo com a tese de António Damásio, pela procura de emoções agradáveis e pela fuga a emoções desagradáveis. Convém, assim, neste momento, descrever em que consiste, na sua perspetiva, a emoção:

As emoções são conjuntos complicados de respostas químicas e neurais que formam um padrão; todas as emoções desempenham um papel regulador que conduz, de uma forma ou de outra, à criação de circunstâncias vantajosas para o organismo que manifesta o fenómeno; as emoções dizem respeito à vida de um organismo, mais precisamente ao seu corpo; a finalidade das emoções é ajudar o organismo a manter a vida. (Damásio, 2004: 72)

Tal definição renega a hipótese que colocávamos de que a emoção pode ser retroativa; a emoção é sempre proativa, o que pode acontecer é que a razão não esteja à altura de a elaborar e de permitir que a mesma aconteça naturalmente com o seu efeito homeostático. Portanto, a questão da manipulação do eu coloca-se ao nível da forma como a razão interpreta erradamente a origem da emoção. Isto é, a emoção negativa exerce um efeito contra libertação, se através da razão se processar um pensamento fixante, hirto e obsessivamente estanque.

Este autor refere que a emoção ${ }^{4}$ se projeta do interior do sujeito para o seu exterior, portanto, é pública. Diz-nos também que a emoção usa o corpo como meio para acontecer e afeta a maneira como numerosos circuitos cerebrais operam; e, além disso, que as respostas emocionais podem modificar tanto a "paisagem cerebral" como a "paisagem corporal". A sua asserção é no sentido de que através do sentimento (dessa emoção), que é privado e se dirige para o interior, se provoca uma certa influência sobre a mente. Diríamos que o sentimento é um mecanismo pacificador, até ao momento em que o racionalismo o trave.

Por fim, alega que esse fenómeno objeto-emoção-sentimento-consciência acontece sempre num tempo e espaço - respeitantes, respetivamente, ao momento em que o nosso organismo se encontra e ao espaço que o mesmo ocupa - que afetam toda a experiência. E conclui que esse impacto será durável se o sujeito conhecer o sentimento ${ }^{5}$ da emoção. Digamos que a emo-

\footnotetext{
${ }^{4}$ Na perspectiva de António Damásio, a emoção como resposta orgânica não é controlável pela nossa vontade. Os seus indutores, quer sejam de origem interna quer sejam de origem externa, podem inclusive ocorrer sem que tenhamos consciência desse acontecimento.

${ }^{5}$ Conhecer o sentimento é uma designação a que António Damásio associa o sentimento do sentimento. O sentimento do sentimento é precedido do sentimento da emoção, em que
} 
ção é um mecanismo hoemostático que resulta da colisão da informação externa com a informação interna, trata-se de uma reação perante a capacidade do indivíduo se ajustar às informações novas, que não se coadunam com o seu si-autobiográfico, com os valores que foi construindo e com a sua persona. O sentimento resultaria, na nossa perspetiva, como o afeto resultante da interação entre a razão e a emoção.

Remetendo-nos a A. Damásio (2004), a consciência passa por três estados, desde o contato com o objeto até ao impacto sobre a mente: o estado da emoção (de que não há consciência), o estado do sentimento (de que ainda não existe consciência) e o estado de sentimento tornado consciente (em que o organismo, nas derradeiras fases do processo, conhece o sentimento, ou seja, onde já existe consciência). Isto é, faz-se um percurso biológico - onde existem a emoção e o sentimento - até um patamar de conhecimento, onde só através da consciência se influencia efetivamente o sujeito que experimenta a emoção e o sentimento; a experiência da emoção é sucedida do sentimento da emoção (no entanto, pode-se ter um sentimento sem que se saiba); e a fase que se segue ao sentimento é ter conhecimento de que se o tem. Não é suficiente saber que existe informação (das diferentes naturezas) para que tenhamos consciência delas; é necessário que a mesma tenha sido interiorizada, consciencializada, compreendida; que tenha, em suma, alterado o nosso organismo, ao ponto de, a certa altura, conseguirmos verbalizar o que se tornou consciente em nós. Todos constatamos que existem as coisas para as quais olhamos, mas só teremos consciência delas, por exemplo, se as desenharmos, pois, assim, a informação é sentida, conhecida, tratada, retida e comunicada.

O nosso comportamento desenvolve-se numa espécie de dialética, entre a emoção e o sentimento, que faz um movimento cíclico. Isto é, como nos diz António Damásio, o facto gera a emoção ${ }^{6}$, que dá lugar aos sentimentos - a representação da emoção em imagens - e que, depois de serem conhecidos - através de uma experiência mental e privada do sentimento -, são susceptíveis de gerar novas emoções. Como o conhecimento dos sentimentos, através da consciência, a emoção também exerce um impacto internamente. Mas este processo de consciência proporciona, além disso, uma

existe a "representação de uma modificação transitória do estado do organismo em termos de padrões neurais e subsequentes imagens" (Damásio, 2004: 323), e consiste na consciência dessas imagens sempre que estas se façam acompanhar de um sentido de si no acto de conhecer e se tornarem salientes.

${ }^{6} \mathrm{Na}$ perspectiva de António Damásio, as emoções tanto podem acontecer quando "o organismo processa determinados objectos ou situações através de um dos seus dispositivos sensoriais" como quando "a mente de um organismo recorda certos objectos e situações e os representa, enquanto imagens, no processo do pensamento”. (Damásio, 2004: 77-78) 
recompensa da emoção sobre o processo do pensamento ${ }^{7}$ através do sentimento. O sentimento é a resposta harmoniosa à emoção, sempre que o pensamento a aceite como fator de reequilíbrio do organismo. No pensamento flui a informação, seja de que natureza for; mas flui sentidamente, é por esse motivo que somos Seres Humanos.

António Damásio (2004) propõe algo de especial importância para o entendimento da sua tese, relativamente à consciência, e que é o facto de que a emoção destina-se à sobrevivência do organismo e que a consciência se destina também a esse efeito (Damásio, 2004). E isto terá de ser entendido tendo como base a sua afirmação de que $a$ homeostasia ${ }^{8}$ "é uma chave para a biologia da consciência" (Damásio, 2004: 60). Nós tornamo-nos capazes de sentir, quando através do nosso pensamento aceitamos as nossas emoções. Esta aceitação é o que nos projeta para um futuro de crescente consciencialização e portanto de sobrevivência, de pulsão de vida.

No que concerne ao desenho, caso este proporcione o fenómeno da consciência, e se neste fenómeno estão sempre subjacentes as emoções, poder-se-ia pressupor, por dedução, que o desenho contribui para a estabilidade do organismo. Logo, coloca-se, neste momento, uma hipótese em aberto que consiste na inferência de que a nossa procura de um sentido se relaciona com a procura de sobrevivência do organismo, ou, mais apropriadamente ao nosso tema, com a procura de equilíbrio. O desenho, nesta perspetiva, é um mecanismo operacional que convoca a cognição, mas também trabalha a informação imagética com o objetivo de ativar situações que ora geram instabilidade, ora reestabelecem a estabilidade; sempre no sentido da homeostasia, da sobrevivência do organismo, da liberdade de viver com que nascemos potencialmente.

Parece possível que tudo se passe num processo de ação/reação sobre a informação externa e interna. É com esses comportamentos que o sujeito se pode aproximar mais dos conteúdos latentes ou mais dos conteúdos manifestos. E, no que respeita à criação, o sujeito, afetado pela emoção, na procura de um sentido que o satisfaça, num processo de imaginação - que se pode concretizar, por exemplo, no desenho -, poderá encontrar-se uma coabitação

7 “(...) o processo a que chamamos mente, quando as imagens mentais se tornam nossas devido à consciência, é um fluxo contínuo de imagens, muitas das quais se revelam logicamente interligadas. O fluxo move-se para a frente no tempo, depressa ou devagar, de forma ordeira ou sobressaltada e, algumas vezes, avança não apenas numa sequência mas em várias. Outras vezes, as sequências concorrem, convergente ou divergentemente, e algumas vezes sobrepõem-se. O pensamento é uma palavra aceitável para traduzir um tal fluxo de imagens." (Damásio, 2004: 363)

${ }^{8}$ António Damásio define homeostasia da seguinte forma: "A homeostasia reporta-se às reações fisiológicas coordenadas e largamente automatizadas necessárias num organismo vivo para a manutenção de estados internos estáveis”. (Damásio, 2004: 60) 
entre os conteúdos latentes e os conteúdos manifestos. E essa coabitação poderá permitir o afastamento do sentimento de desprazer, mas pode, no fundo, consubstanciar a expressão dessa procura numa forma representada e descoberta, assim como na constituição de novas atitudes e tendências, na medida em que a consciência se alargue.

A imagem obtida pelo sujeito no termo da sua busca - por vezes mal revelada ao seu autor - surge, então, como a expressão de um estado psicológico preexistente e, também, o que se nos afigura mais importante, como uma reação, como uma tomada de posição sobre si mesmo. A imagem é um momento, não apenas da tomada de consciência confusa das tendências e das atitudes, mas também da constituição destas. No decurso do ato de imaginar, com efeito, as tendências tomam forma, fixam-se exprimindo-se, por via dos objetos que elas põem a descoberto. (Malrieu, 1996:116)

Esta consubstanciação da forma talvez resulte num maior equilíbrio emocional, na medida em que a informação, que é externa e estranha, se coadune com a informação que é interna e sobre a qual é reservado sempre um (mais ou menos profundo) sentimento. O percurso para chegar a esse estado proporciona uma alteração do organismo, muda o estado de sentimento atual, introduzindo novos sentimentos, próprios das imagens que se manifestam agora, mas que podem ter origem na memória. Mas as respostas/mensagens que cada emoção constitui requerem um seu conhecimento no sentido de que tenham um efeito modificador no organismo, para uma melhor e mais inteligente gestão das emoções que normalmente agitam a aparente neutralidade do equilíbrio. Após a etapa em que se sente essa emoção, onde esta se transforma numa representação de imagem, é necessária a ação na consciência nuclear sobre esse fenómeno e, só depois, se poderá sentir o sentimento (conhecer o sentimento da emoção). Por ordem do pensamento, da razão, a emoção foi compreendida e consciencializada, deixou de ser estranha, permitindo que o sentimento, da informação que gerou a agitação, restitua a harmonia à força selvagem do instinto de defesa próprio do organismo animal com que somos constituídos.

Um conjunto de pensamentos, que se sucedem continuamente, pode, na ótica de António Damásio (2004), induzir um conjunto de emoções que se sucedem igualmente de forma contínua - o que se reflete no comportamento humano. Nesta interação entre o pensamento e a emoção, pode-se gerar um processo mental dinâmico. É este dinamismo que quebra o neutralismo da razão, é este dinamismo des/reequilibrador que cria condições e a necessidade de procurar novas informações novos pensamentos adaptados às emoções do momento. A liberdade funda-se na capacidade reequilibradora da razão. Mas, sem desequilíbrio não existiria a necessidade e a possibilidade de um reequilíbrio que só por si é um manifesto de felicidade. Portanto, é 
necessária a emoção que agite a fugaz letargia e é necessária a razão que elabore essa agitação.

Neste processo, incluímos o desenho como seu fator, tendo em conta que talvez faça emergir emoções, sentimentos e o conhecimento do sentimento dessas emoções, sempre que esse desenho aconteça no contexto da criação. Na realidade, sendo o desenho eminentemente improvisador e não premeditado, naturalmente lança o seu autor para o desconhecido e para o confronto com novas informações (as do elemento de referência observada e a do próprio desenho que se elabora).

\section{A informação entre o verbal e o não-verbal no fenómeno da consciência através do desenho}

Não se pode abreviar o percurso de consciencialização, que tem origem biológica e culmina num estádio mental elevado, num mero processo que vai da emoção ao conhecimento do sentimento da emoção. António Damásio (2004) descreve detalhadamente esse processo ${ }^{9}$. O conhecimento, no seu sentido mais complexo, é "consequência direta de um sistema nervoso que, sendo capaz de consciência, também está equipado com uma memória vasta, com uma poderosa faculdade de classificar itens na memória, com uma faculdade original de traduzir todo o espetro do conhecimento sob a forma de linguagem e com uma faculdade realçada de manter esse conhecimento presente na mente e de o manipular de forma inteligente" (Damásio, 2004: 352). Ou seja, em todo o processo intervêm a memória, a linguagem ${ }^{10}$ e a inteligência: três das componentes que o nosso cérebro potencia, que podem ser desenvolvidas conforme o tipo de atividade que o sujeito tiver, mas sempre em prol da expansão da vida e da consciência.

Remetendo-nos para o desenho como linguagem ${ }^{11}$ visual, portanto, não-verbal, podemos crer que é uma atividade que permite ao sujeito expe-

${ }^{9} \mathrm{O}$ percurso do estado de vigília à consciência passa por: estado de vigília, detecção do valor do objecto, atenção elementar, faculdade de produção de imagens; proto-si; objecto; modificações do proto-si; imagens do objecto; mapa de segunda ordem da relação organismo-objecto; consciência nuclear (inclui o si nuclear); atenção realçada e memória de trabalho; memória convencional; memória autobiográfica; si autobiográfico e consciência alargada; linguagem; criatividade; consciência; outras criações. (Damásio, 2004: 352)

10 "A coroa de glória da linguagem vem da sua capacidade de traduzir, com rigor, os pensamentos em palavras e em frases, e as palavras e as frases em pensamentos; da sua capacidade de classificar o conhecimento, rápida e economicamente, sob a capa protectora de uma palavra; da capacidade para exprimir construções imaginárias ou abstracções remotas através de uma palavra simples e eficaz." (Damásio, 2004: 138)

11 Linguagem designa "qualquer sistema ou conjunto de sinais, fonéticos ou visuais, que servem para a expressão do pensar e do sentir”. (cf. Costa, 1998: 1009) 
rimentar um certo tipo de fenómeno de consciência, que modifique a estrutura do pensamento e o conhecimento anterior ao ato de desenhar. Atentemos a afirmação, no contexto do desenho, de J. Molina:

A riqueza do léxico que ele gerou está, sobretudo, no que define como experiência de conhecimento sensível de seu trabalho, no qual determina os estados de ânimo em que se fixa sua ação, no que estabelecem as operações que modificam o nosso conhecimento do objeto e a estrutura do nosso pensamento. (Molina, 2005: 23)

O desenho remete-nos para o conhecimento não-verbal. É um tipo de conhecimento que poderá suscitar o conhecimento verbal. Mas este não é basilar para o ato de criar através do desenho; pode, eventualmente, existir $a$ priori ou a posteriori, mas não no próprio ato. Como verificamos na tese de Ana Leonor Rodrigues (2003), o desenho poderá, na sua qualidade de "meta-representação", constituir um meio de comunicação através de conteúdos mais latentes, de tal forma que essa comunicação se torna "pura". O que nos aproxima, de certa forma, das, designadas por António Damásio (2004), disposições. Prestemos, então, atenção ao que profere Ana Leonor Rodrigues:

Por outras palavras, quem desenha tem a capacidade de conseguir imprimir informação vinda de uma área menos consciente e discursiva da mente (o que, no fundo, é uma manifestação de aspetos latentes nela contidos), e quem vê a capacidade de sentir essa infra-informação que remete para uma meta-representação do representado e que constitui afinal um estado puro de comunicação entre mentes, codificada nas ordens estruturadas da materialidade e da conceptualidade do desenho de notação rigorosa. (Rodrigues, 2000: 50)

Quando falamos de conhecimento, deve-se especificar a que tipo de conhecimento nos referimos, sabendo nós que o conhecimento não é só o que se verbaliza e que se retém sob essa forma potencialmente na nossa memória, como se tratasse de um acumular de informação descritiva. $\mathrm{O}$ que o nosso sentido da visão capta é informação susceptível de ser percebida; daí a designação de perceção visual. O que a nossa visão capta é informação à qual podemos associar a verbalização como meio de a traduzir, tratar e comunicar. O desenho remete-nos para um tipo de conhecimento que existe autonomamente em relação ao conhecimento verbalizável, mesmo que se possa anexar a este. No entanto, apesar de se colocar a hipótese de se dar primazia ao conhecimento que o desenho nos faculta, não podemos esquecer que o conhecimento no seu sentido lato requer a complementaridade de conhecimentos de outras naturezas. Isto, partindo da premissa de que somos um sistema individual e vivemos em sistema coletivo, algures num sistema universal. 
Na verdade, o conhecimento, num nível de desenvolvimento superior, "desde o simples ao complexo, desde a imagética e não-verbal até ao verbal e literário, depende da capacidade de cartografar aquilo que acontece ao longo do tempo, no interior do nosso organismo, à volta do nosso organismo, ao nosso organismo e com o nosso organismo, numa sucessão causal e incessante" (Damásio: 2004: 221). O conhecimento não é senão a cartografia das realidades a que temos acesso.

\section{A consciencialização no ato de desenhar}

No que nos diz respeito, contextualizamo-nos na situação em que o organismo tem contato com um determinado objeto através do sentido da visão ${ }^{12}$. Nesse fenómeno, ativa-se o processamento da imagem do objeto (do exterior) ao nível neuronal - segundo padrões neuronais -, que responde de acordo com a especificidade do indutor a que o objeto pertence (o indutor pode reportar-se a outros objetos em que a experiência provocou um estímulo específico e que pode condicionar o tipo de emoção desencadeada perante o objeto presente) (Damásio, 2004). Por sua vez, a emoção implica a transmissão de sinais a determinadas partes do cérebro e do corpo. Relembramos que, na ótica de A. Damásio (2004), podemos sentir a emoção que se desencadeou e, posteriormente, conhecer esse sentimento e só nesta última etapa se processou a consciência da modificação que a emoção poderá ter provocado no nosso organismo no momento em que interagimos com esse objeto através da nossa perceção visual. Se não conhecermos, isto é, se não representarmos a relação entre o objeto e o organismo, não teremos consciência de que as modificações se efetuaram no nosso próprio organismo e que foram provocadas por esse determinado objeto - isto, mesmo que o organismo tenha sido sujeito a ajustamentos motores a que obriga o prosseguimento da recolha de sinais acerca do objeto, ou impulsionado à resposta através de emoções.

\section{$O$ ato de desenhar e o ato de conhecer para uma modificação da consciência}

No que respeita ao desenho, pode-se conjeturar que é uma atividade que altera o conhecimento que o autor tinha antes do ato, e que dessa forma a sua

12 "Este objecto é «implementado» nos córtices iniciais visuais, o conjunto de córtices em que os sinais vindos das retinas dão conta das várias dimensões dum objecto, tais como cor, forma, e movimento." (Damásio, 2004: 191) 
relação com o desenhado será diferente da que tinha anteriormente. De uma forma mais específica, J. Molina diz-nos que "cada representação parece estabelecer uma relação irreversível com aquilo que denomina, ao estabelecer o conhecimento que temos dele mesmo, pelo que cada figura se converte num símbolo clarificador e numa alavanca para o conhecimento possível de uma nova relação" (Molina, 2005: 77). Vejamos a afirmação de António Damásio, que nos parece ter uma tese que nos aproxima à de $\mathrm{J}$. Molina:

O empenho do organismo num dado objeto intensifica a sua capacidade de processar sensorialmente esse objeto e também aumenta a oportunidade de envolvimento com outros objetos - o organismo está pronto para outros contatos e outras interacções. O resultado global de todo este processo é um estado de maior alerta, uma focagem mais nítida e uma maior qualidade de processamento de imagem. (Damásio, 2004: 215)

\section{A atenção e a consciência no ato de desenhar}

Relativamente à atenção e à sua relação com a consciência, António Damásio (2004) diz-nos que uma atenção dirigida a um objeto externo significa, normalmente, que a consciência está presente. Afirma, também, que se a atenção se mantiver duradouramente "em relação aos objetos que são necessários para um comportamento adequado a uma determinada situação" (Damásio, 2004: 115), pode-se inferir que a consciência também está presente efetivamente. Do que o autor conclui que a consciência imanente da atenção "requer um período de tempo prolongado e uma concentração sobre os objetos apropriados." (Damásio, 2004: 115) Mas acrescenta que a consciência também pode estar presente, caso a atenção seja dirigida a um objeto interno. $\mathrm{Na}$ opinião deste autor, a atenção e a consciência interatuam em forma de espiral ascendente. No que diz respeito à consciência nuclear, é a atenção elementar que a precede e dá base aos processos que a geram. Numa outra etapa, a um nível superior, possibilita-se a geração de uma atenção de alto nível susceptível de ser direcionada para um estímulo preciso e permanecer aí durante longo tempo (Damásio, 2004).

No desenho, a apreensão do mundo material requer uma atenção acrescida no momento da observação (sobre o que constitui a referência material do desenho e sobre o próprio desenho, quer tenha uma referência actual, quer tenha uma referência com origem na memória). De facto, o desenho obriga a uma reconstrução do que a visão capta e, nesse sentido, Ana Leonor Rodrigues diz-nos que "o ato de desenhar é então um modo de apreensão do mundo material que contribui para a consciência de si, para o contato com esse mundo material e para a construção do que chamamos realidade" (Rodrigues, 2000: 65). 


\section{Os conteúdos latentes e a intersubjetividade}

Relembre-se que, como nos chama a atenção António Damásio (2004), a consciência nuclear tanto pode ser produzida numa situação em que o organismo interage com um objeto atual como com um objeto recordado. Nesta última situação, o sujeito recorre à memória disposicional, que é "um espaço em que as memórias disposicionais contêm registos de conhecimento implícito, com base nos quais imagens podem ser reconstruídas no recordar, movimentos podem ser gerados e o fluir mental pode ser facilitado." (Damásio, 2004: 253) Logo, o recordar um objeto explicita o que antes era implícito nos vários aspetos mencionados relativamente à reação do organismo ao objeto.

Poderá a criatividade ser um motor de estímulos para que essas disposições emirjam, e poderá o desenho acentuar esse processo no sentido que vejamos o que anteriormente não víamos - ou não conhecíamos, simplesmente porque o objeto não tinha interagido com o nosso organismo, e, portanto, este não terá sofrido nenhuma alteração com origem nesse objeto. A atividade do desenho não é uma constatação do real, ela torna o mundo cognoscível, na medida em que "desenhamos e vemos ou desenhamos para ver." (Copón, 2005: 533) A nossa consciência alarga-se na medida em que "se cria o mundo, como totalidade referencial de signos" (Copón, 2005: 533) pois ele é "um artifício" (Copón, 2005: 533), é o que a nossa mente consiga construir cognitivamente e que se pode proporcionar com a ativação do pensamento através do desenho na sua qualidade de representação e meio de criação.

Convém relembrar o que afirma António Damásio relativamente aos conteúdos mentais (onde se incluem os da perceção visual): "todos os conteúdos mentais são subjetivos e a força da ciência provém da capacidade de verificar a consistência de muitas subjetividades individuais" (Damásio, 2004: 106). Logo, apesar de o desenho, que resulta da perceção visual de um autor, traduzir uma representação a que atribuímos uma identificação objetiva, requer uma "verificação de sua consistência"13. O que se prende com uma intersubjetividade, ou seja, de considerar que "com a possibilidade de entrar, pelo diálogo nomeadamente, numa relação com o outro onde as posições sejam ao mesmo tempo diferentes e intermutáveis é o que dá ao mundo

13 António Damásio refere que para inferir razoavelmente acerca dos estados humanos privados baseados no comportamento externo, tem de se articular: "l) certas manifestações externas, por exemplo, a vigília, as emoções de fundo, a atenção, certos comportamentos específicos; (2) as correspondentes manifestações internas do ser humano que têm esses comportamentos, tal como são relatados por esse mesmo ser; e (3) as manifestações internas que nós, enquanto observadores, podemos verificar em nós mesmos, quando nos encontramos em circunstâncias equivalentes às do indivíduo observado." (Damásio, 2004: 106) 
a sua espessura, já que ele se enriquece de pontos de vista diferentes do meu, mas também a sua objetividade, pelo menos a título de exigência ideal de um mundo comum" (Clément, 1999: 203). Dessa forma, contribui-se para um enriquecimento de perspetivas, e no seu cruzamento obtém-se uma objetividade tendencialmente maior.

A memória dos conhecimentos implícitos interessa-nos particularmente, porque nos indica que existem disposições cuja ativação se reflete a vários níveis, a que nós associamos uma potencialidade para agir seja no recurso à memória, no recurso aos movimentos ou no recurso ao mental (no sentido lato). Isto é possível pelo facto de, segundo António Damásio (2004), as disposições reservarem ao nível da memória imagens que se apreenderam com experiências passadas e que facilitarão a reconstrução de uma imagem semelhante a partir da memória; além disso, ainda segundo o raciocínio do autor, as disposições podem facilitar o processamento de imagens que se apreendam no presente. Esta perspetiva dirige-nos para o campo da intuição no ato da criação e da representação.

António Damásio (2004) considera que existem conteúdos da memória autobiográfica que se mantêm inconscientes. Eles podem ficar sempre neste nível ou então podem ser reconstruídos, mas de uma forma diferente da originária. Apesar disso, podem funcionar, a esse nível, promotores da emergência, ao nível consciente, de outros conteúdos, sob a forma de factos ou emoções (Damásio, 2004). A relação ${ }^{14}$ entre estes conteúdos e os que existem de facto no presente ao nível consciente pode não ser compreensível à partida. No entanto, segundo este autor, as relações podem ter a ver com experiências do passado ou com uma experiência inconsciente do presente (Damásio, 2004).

De facto, António Damásio (2004) não nos diz que pelos processos de imaginação ou criação os conteúdos implícitos possam vir a ser conhecidos, mas podemos presumir que isso aconteça com alguns deles, apesar de não podermos descrever de que forma isso poderá acontecer. Relativamente aos conteúdos desconhecidos, verifiquemos, para concluir, o que Philippe Malrieu afirma:

As obras de arte têm como função realizar, no sentido forte do termo, aquilo que no sonho não passava de uma aparência e, no mito, nada mais era do que significação. A imaginação põe a descoberto um real oculto e desconhecido,

14 António Damásio, no contexto da sua tese com carácter de análise neurocientífica, utiliza a palavra «ligação» para se referir à relação entre coisas e acontecimentos como terão acontecido no pretérito, assim às representações mentais dessas coisas e acontecimentos, de acordo com as nossas experiências, e refere-se também à relação de união neural entre os circuitos cerebrais que se forma para que o registo das coisas e dos acontecimentos se mantenham e para que estes se possam transferir para padrões neurais explícitos. 
escondido sob o real conhecido, «natural». Ela faz com que vejamos, escutemos e pensemos que existem, a um nível mais profundo, outras realidades a que não estamos habituados. (Malrieu, 1996: 81)

\section{As imagens (mentais) no contexto (para além) da consciência}

Segundo a tese de António Damásio (2004), considera-se a mente como o meio onde se produzem as imagens que correspondem às percepções externas ou às percepções de que nos recordamos. O autor alega, ainda, que a mente resulta nessas imagens quando acrescidas da presença do eu.

O desenho não nos remete para um fenómeno de consciência só quando o autor está perante o objeto (que pode ser o próprio desenho-objeto) do qual capta uma imagem, mas também quando o desenho se processa ao nível da imaginação. Diríamos, também, que, numa e noutra situação, o desenho não se cinge à utilização cognitiva dos mecanismos de representação, envolve a emoção e estados mentais e físicos, quer seja in loco ou através da memória, conforme nos diz António Damásio: "a reconstrução desse conjunto de acomodações do organismo ao objeto recordado gera uma situação similar à que ocorre quando se percebe um objeto externo diretamente" (Damásio, 2004: 216). O autor, inclusive, ressalva que, apesar do tipo de estímulo ser diferente, a consciência é igual.

Assim, as imagens podem ser construídas do exterior do cérebro para o interior (todo o objeto que é percebido, o que tem a ver com qualquer modalidade sensorial, portanto não são só da ordem do visual, pode inclusive ser somato-sensorial); ou do interior para o exterior (quando se trate de reconstruir os objetos com base na memória) (Damásio, 2004). O que nos remete para J. Bronckart, quando refere que imagem mental é:

Representação interiorizada e estruturada de um objeto ou de um acontecimento, anteriormente percebida e construída pelo sujeito. Da sua interação com o meio, o organismo conserva traços internos, efémeros ou permanentes; a sua presença torna possíveis os processos de identificação, de discriminação, de evocação e de antecipação. ${ }^{15}$

Desenhar para criar tem como base essas potencialidades. O desenho-processo para a criação permite aprender algo mais sobre si (autor dos desenhos) numa conjuntura de processamento de imagens, em que estas são discriminadas e/ou evocadas e/ou antecipadas. Mais concretamente, abordamos aqui o desenho para a criação no contexto do processo de imagina-

15 Imagem mental - cf. J.-P. Bronckart, J.-P., in Doron, Roland e Parot, Françoise - Dicionário de Psicologia. Lisboa: Climepsi, 2001, p. 404. 
ção, entendida aqui, num sentido lato, como "aptidão para formar e para ativar imagens mentais, na ausência de qualquer modelo percebido; como capacidade de combinar imagens em quadros ou em sucessões; (na imaginação criadora) como evocação de acontecimentos potenciais, mas que nunca foram percebidos pelo sujeito" 16 .

Quando aplicamos a designação de imagem mental à imaginação (no sentido lato, como faculdade de ter imagens mentais), seguimos a definição de Louis-Marie Morfaux, que diz que consiste na "capacidade de representar, com maior ou menor riqueza ou precisão, seres ou coisas, de maneira análoga a perceção traduz o aspeto sensorial do conteúdo, mas, distintamente desta, a representação obtém-se por um processo interno, subjetivo, sem excitação de órgãos sensoriais." 17

Sugerimos que se o desenho envolve a imaginação entendida como o resultado do cruzamento e complementaridade destas definições. O desenho proporciona ao autor a emergência de imagens, quer sejam meramente neuronais, quer tenham origem na memória, quer sejam provocadas pela perceção sensorial, quer sejam inventadas. $\mathrm{O}$ desenho para a criação tanto pode potenciar a imaginação ao nível das imagens mentais, que se encontram na memória, como ao nível inventivo, em que se criam imagens novas, como, ainda, ao nível da imaginação criadora, em que se inventam representações mentais de aspeto sensorial. A imaginação pode ser um processo em que se criam imagens novas, que resultem da relação eu - não-eu, ou de uma relação entre a nossa consciência e o que ainda não está consciente. Numa palavra, o desenho acontece num processo em que atuam as imagens inconscientes, aquelas que agem sobre o nosso organismo ao nível perceptual e aquelas que se encontram numa memória mais acessível.

Podemos, assim, entender melhor o que diz Philipe Malrieu, quando se refere ao imaginário ${ }^{18}$, e que nós entendemos que se relaciona com o facto de que o conhecimento de nós próprios pode ser proporcionado pela consciencialização e materialização das imagens, quer tenham origem interna quer tenham origem externa.

O sujeito que imagina não procura deixar os acontecimentos - percepcionados ou memorizados - lado a lado; o que ele pretende não é tanto que eles sejam apenas classificados, mas sim que graças às redes nas quais irão situar-se, lhe permitam aprender algo sobre si mesmo. (Malrieu, 1996: 238)

16 Imaginação - cf. Bronckart, J.-P., ibidem, 404.

17 Imaginação - cf. Morfaux, Louis-Marie in Souriau, Etienne, in Dicionário Akal de Estética. Madrid: Ediciones Akal, D. L. 1998, p. 670.

18 Domínio da imaginação criadora que compõe diferentes representações sensíveis dos objectos ou das situações vividas. (Imaginação - cf. Doron, R. e Jalley, E., in Dicionário de Psicologia, p. 404) 
O desenho medeia, necessariamente, o interno e o externo, na medida em que o desenhador-autor concentra a sua atenção (a partir da sua mente, que é o interno) ao objeto visível (externo). Trata-se de uma interação que envolve também imagens mentais e imagens percecionadas. O objeto visível pode ser eventualmente algo que a visão alcança (como imagem percepcionada) para que possa desenhar analogicamente, mas é, além disso, sempre, o desenho-objeto (ele próprio um objeto externo). $\mathrm{O}$ organismo interage com esse objeto, com o qual processa uma imagem da qual fica ciente, a partir da qual terá a possibilidade de criar novos objetos/imagens. O que não só potencia a capacidade criadora do indivíduo como lhe proporcionará um entendimento maior de outros objetos. Tais competências devem-se ao fenómeno da consciência, que, segundo António Damásio, "resulta num estado de vigília realçado e numa atenção dirigida, sendo que ambas melhoram o processamento das imagens e permitem optimizar tanto reações imediatas como o planeamento de reações futuras" (Damásio, 2004: 214-215).

O sentido de pertença das imagens é, no fundo, o conhecimento de que as imagens foram incorporadas e já fazem parte da estrutura mental do sujeito. Este processo ${ }^{19}$ será potenciado se o sujeito agir com base no raciocínio e na memória. $\mathrm{O}$ desenho, por sua vez, é um processo que permite ao desenhador constituir-se como proprietário das imagens, e, dessa forma, atuar sobre elas. Mas só é proprietário, se atingir o estado de consciência em que pode ser "espetador, entendedor, conhecedor, pensador e possível ator" (Damásio, 2004) dessas imagens (representadas a partir das modificações que a interação organismo-objeto provocaram). É na gestão de relações e reações do contato do organismo com um objeto, que encontramos a mais-valia do desenho na medida em que "desenhar é um processo de precisão mediante o qual se evidenciam elementos que até então não eram reconhecidos como unidades pertinentes de algum conhecimento." (Molina, 2005: 78) Ou seja, o conhecimento amplia-se e, por consequência, também a consciência.

19 “Além de proporcionarem o sentimento de conhecer e o realce do objecto, as imagens do conhecer, complementadas pela memória e pelo raciocínio, formam a base simples das inferências não-verbais que reforçam o processo da consciência nuclear. Estas inferências revelam, por exemplo, a estreita ligação entre a regulação da vida e o processamento de imagens, que está escondido no interior da perspectiva, pronto a ser esclarecido assim que for possível realizar a seguinte inferência: se estas imagens contêm a perspectiva deste corpo que agora sinto, então estas imagens estão no meu corpo, são minhas. Quanto ao sentido de acção, está contido no facto de certas imagens estarem estritamente ligadas a certas opções de execução motora. Daí resulta o nosso sentido de acção potencial: estas imagens são minhas e posso actuar sobre o objecto que as causou”. (Damásio, 2004: 215) 


\section{O ser holístico no desenho-processo}

Claro que podemos considerar que existem atividades que tendem a utilizar mais determinados grupos de áreas do cérebro em detrimento de outros; no entanto, é importante ter sempre presente que a atividade cerebral é uma atividade holística, não podendo assim separar 'ver' de pensar, raciocinar de sentir, e assim por diante, devendo entender o ato de ver como uma situação dinâmica e mobilizadora do cérebro e não como um registo passivo daquilo sobre que o olhar passa. Para ver é necessário usar a consciência, e vê-se, realmente, quando se sabe que se vê. (Rodrigues, 2000:75)

Esta afirmação e a análise que vimos fazendo permitem-nos reforçar a ideia de que o desenho não é uma área de ação que se limite a uma técnica de representação com base na captação de informação visual. A individualidade do autor, como um todo, é projetada na exploração do desenho através da expressão e da criação, pois envolve várias facetas, potencialidades de diferentes naturezas, uma intencionalidade de inovar e de criar algo de novo nesse processo fenomenológico. Nas palavras de Ana Leonor Rodrigues, "o objeto de desenho não existe anterior a nós, ele é um resultado quer da nossa relação espacial e fenomenal com o mundo, quer um resultado direto da nossa vontade e capacidade de ação." (Rodrigues, 2003: 65) A novidade que se gera no fenómeno do desenho-processo não se reduz à criação de algo que simplesmente não existia sob o ponto de vista formal. A inovação traduz algo de novo que se gerou ao nível psíquico do autor, por um lado, a modificação da sua consciência, por outro lado, as caraterísticas que refletem a individualidade desse autor. Supomos que essa individualidade que o desenho transparece é de facto o encontro de uma identidade ${ }^{20}$, que o desenho concentra em si. O que na experiência total do autor constitui uma sua projeção holística, que se traduzirá num desenho-objeto individualizado.

A partir daquele que desenha e das variedades de personalidade, imaginação, talento, estado de espírito ou saúde, sensibilidade, habilidade manual, que o podem caraterizar, estas vão imprimir ao resultado do fazer um cunho pessoal que o individualiza, não apenas no seu sentido, mas na própria forma que cada elemento adquire. (Rodrigues, 2003: 65)

O registo expressivo da emotividade do autor do desenho não tem só a ver com o vigor do traço, com a espessura ou outras marcas, tem também a

20 “A identidade pessoal é uma construção dinâmica da unidade da consciência de si, através das relações intersubjectivas, das comunicações de linguagem e das experiências sociais. A identidade é um processo activo, afectivo e cognitivo de representação de si no meio que o rodeia, associada a um sentimento subjectivo da sua permanência." (Identidade - cf. Selosse, J., in Roland Doron e Françoise Parot - op. cit., p. 398) 
ver com as prioridades pelas quais se optou, seja ao nível de expressão, seja ao nível de organização, seja ao nível do tema, seja ao nível da técnica, e o tipo de representação. A emotividade do autor é revelada pela expressão do desenho. Mas o sentimento é revelado pela escolha do que representa e que tipos de associação se fizeram. Se na revelação da emotividade observamos o facto de o autor ter dado prioridade a um determinado gesto em detrimento de outros, ou ter dado prioridade à expressão da mancha de um pormenor em detrimento de outros; por outro lado, a opção que adotamos pelo agrupamento de um objeto a outros, segundo a afinidade pessoal que incutimos nesse desenho, revela a prioridade que demos a determinadas imagens, secundarizando outras que recusámos porque o sentimento em relação a elas as tornou menos importantes. Ou seja, interferiu nas escolhas o nosso juízo de valores. Assim, o desenho-processo obedece à faculdade da razão e pode percorrer o reduto das emoções mais profundas, ou até, nas palavra de Ana Leonor Rodrigues (2003), ser o vestígio das características vegetativas.

Consideramos ser difícil verificar a que corresponde a manifestação explícita do consciente de um desenho e a manifestação inconsciente nesse mesmo desenho. No entanto, existem conteúdos inconscientes que influenciam o eu na forma como atua manipulando os elementos expressivos do desenho. Sendo que estes, ao serem materializados, tornam o desenho susceptível de uma leitura com base na interpretação de sentidos e sensibilidade estética que constituem um simulacro das motivações do autor no seu total. $\mathrm{Ou}$, pelas palavras de Ana Leonor Rodrigues, o ato de desenhar seria um "acontecimento cuja leitura pode existir plena de sentidos e possibilidades estéticas" (Rodrigues, 2003: 17).

No sentido de verificar a asserção de se o desenho é um simulacro do autor na sua realidade holística, atentemos a que o conhecimento que nos permite ter uma consciência das coisas que nos envolvem, se apoia, segundo Copón, numa pesquisa em que se relaciona "a estruturação da linguagem com as possibilidades de mediação e mudança sobre o real que nos oferece" (Copón, 2003: 430). Trata-se de um percurso que, segundo o nosso livre-arbítrio e em função das nossas intencionalidades, proporciona uma interação com o meio com o recurso ao desenho como forma de conhecimento através da representação. Mas é uma forma de conhecimento que não se reduz ao mero processo de representação, trata-se de algo a que Copón (2003) se refere como uma tentativa de captar "a fluência do vital como conexão" (Copón, 2003: 430) ou "compreender mediante o mapa que traçamos ao representar a lei de escalas e conexões da vivência" (Copón, 2003: 430).

O desenho faz parte, na sua concepção mental, de um sistema, ou melhor, da realidade sistémica do ser, onde prepondera a visão como "o encontro, como numa encruzilhada, de todos os aspectos do Ser" (Merleau-Ponty, 2004: 68). O conhecimento talvez não se remeta só ao intelecto, ou 
só à razão, isso seria remetermo-nos a uma parte do sistema, ao "cogito" cartesiano. O conhecimento é produto de um todo na relação sistémica entre as realidades internas e as realidades externas. Sugerimos que o desenho será um contributo para que esse todo seja mais expandido. E essa expansão tem a ver com uma dialética entre a perceção e o ato de descrever através da representação, ou, usando os termos de J. Molina, "um diálogo, uma disposição para ver as possibilidades de compreensão, iluminação do mundo através da análise plástica." (Molina, 2005: 43) A perceção completa-se com a descrição e vice-versa. De facto, ver não é suficiente para que a perceção seja efetivada. O exercício de descrever aquilo que se vê será um fator de consciencialização da visão de algo, no ato de perceção visual. Sublinhe-se que o desenho é aqui entendido como técnica acessível e estimulante que poderá proporcionar, conforme o indivíduo se ajuste ao processo, circunstâncias facilitadoras de uma expansão da consciência alargada. De facto, uma vez que o desenho envolve o corpo, a cognição, a sensação, a emoção, o sentimento, a razão e a intuição, poderá ser uma atividade que pela sua abrangência nos facilite o percurso em direcção ao ser integral.

Sendo o pensamento resultado da atividade da mente, é um processo complexo que mobiliza todo o sujeito pensante na sua unicidade inteligível, afetiva, corpórea e social. Um pensamento, por mais claro e linear que apareça, não tem uma existência pura, resulta sempre da mobilização total dessa unicidade do sujeito. (Rodrigues, 2000:191)

O desenho inclui as duas faces distantes do ser do sujeito, a sensibilidade e a razão. Desenhar pode, na opinião de J. Molina (2003), usando o número de uma forma intuitiva (presumimos), mediar a "experiência sensível" e o que é emanado das "leis puras do pensamento". Trata-se de uma correspondência entre a relação entre dimensões, que o pensamento nos faculta, e a sua corporização através do registo gráfico e redutivo do desenho.

O número, a linguagem verbal e a imagem são realidades presentes no desenho, as primeiras de forma implícita, a terceira explicitamente. Se tratamos de escala, de proporção e de quantidade, não prescindimos do número; se desenhamos as realidades a que naturalmente atribuímos definições e nomeações, não prescindimos da linguagem verbal; o facto de o desenho ser imagem, não nos permite atribuir-lhe uma outra forma de se manifestar. As três realidades são parte de um sistema que tem origem na mente do Homem no seu caráter holístico. Ora, o eu e sua consciência existem, na medida em que o consciente estabelece contacto com o não-eu, o ainda não consciente. E a facilitação dessa relação que move o ato de desenhar.

$\mathrm{O}$ desenho-objeto é um registo que se insere num contexto da história pessoal do seu autor, mas, além disso, insere-se no seu contexto sociocultural. $\mathrm{O}$ desenho pode, mesmo, refletir o modo de ser das pessoas de uma determinada época (Molina, 2003). Será difícil perceber as circunstâncias 
psicológicas do autor, pela distância em relação à noção do que pensa ou sente esse autor. Todavia, o desenhador-autor é o reflexo de uma sociedade. Sendo o desenho, indiretamente, uma projeção da sociedade, não pode deixar de ser também a projeção do desenhador-autor, pois o que seja uma referência à sociedade é-o sempre conforme a visão que o autor tem da mesma. Esta visão é influída pela consciência que o autor tem de si. Inclusive, poderá haver uma correlação entre a consciência de si do sujeito e a consciência que tem do mundo. A consciência de si seria, nesta ótica, um fator de uma consciência mais alargada do mundo. Assim sendo, entende-se por que um desenho-processo, absorvendo todo o ser do autor ${ }^{21}$, pode ser uma visão do mundo que o envolve. Mas, tratando-se do plano individual, o ato de desenhar, sendo holístico, concentra no desenho-objeto, segundo Miguel Copón, uma qualidade energética que "provém da quantidade de informação que é capaz de capturar e apresentar com sentido" e que "dependerá da implicação vital do autor com o objeto, com a linguagem que lhe serve de mediação" (Copón, 2003: 431).

Poderemos socorrer-nos de uma base científica ao nível do funcionamento cerebral para perceber melhor o holismo em que fundamos o fenómeno do desenho, e apoiamo-nos, por exemplo, no que Juan Mendonça nos diz, relativamente a duas tendências que o nosso cérebro pode ter, mais racional ou mais intuitiva, ou seja, mais analítica ou mais holística, respetivamente.

Coloca-se então a questão da correspondência entre estas duas formas de linguagem (digital/analógica) e os dois modos de tratamento da informação (analítico/holístico) atribuídos aos dois hemisférios cerebrais. Ela pode-se exprimir sob a forma de uma hipótese a verificar: o hemisfério esquerdo representaria o «cérebro digital», cérebro da reflexão, do raciocínio e da lógica; e o hemisfério direito, o «cérebro analógico», o da intuição e da imaginação, da fantasia e do sonho. (Mendonça, 1998: 115)

Do ponto de vista do processo do desenho, a tendência parece-nos ser oscilante e dialética. A nossa abordagem centra-se no desenho para a criação, por isso, ao nível do tratamento de informação, cremos que a situação se carateriza, também a este nível, de forma mais holística. Não faz muito sentido que no desenho se proceda à aprendizagem da análise das formas unicamente segundo a respetiva acuidade da perceção visual. Presumivelmente, também não faz muito sentido criar segundo um propósito meramente analítico. Será mais coerente passar pela primeira fase, da análise e depois permi-

21 "Comove pensar poder ter sido o amor a mover a acção de desenhar, mas a ideia condensa perfeitamente, numa imagem, aquilo que de nós é mobilizado: por um lado a mente; a inteligência analítica, o sentido ordenador, a consciência do observar, mas também a sensibilidade e os afectos, e, por outro lado, sempre o olhar. Tudo isto de nós está contido no desenhar." (Rodrigues, 2003: 22) 
tir que a intuição conduza à gestão das aprendizagens anteriores (alegadamente da responsabilidade do hemisfério esquerdo, segundo uma orientação analítica) por vias holísticas, mais libertas da referência objetiva e da deliberação consciente.

Reiterando ainda a ideia de identidade, como projeção do eu holístico, frisamos que nem só pensamento, nem só físico, nem só perceção, nem só mental, nem só sensorial, nem só emocional, nem só afetivo, nem só sentimental; mas sim tudo em conjunto, num processo dinâmico. A nossa asserção acerca do desenho pode ter como referência o que José Bettencourt diz acerca da pintura, com referência ao pensamento de Maurice Merleau-Ponty:

Reunimos os elementos necessários para explicitarmos que em pintura se não verifica um problema da profundidade, um problema da linha, um problema da cor e um problema do movimento, mas sim um único grande problema: o da expressão do mundo, o de um modo de abertura ao Ser sem o conceito que não será apanágio da pintura, mas em que ela se funda, que ela especialmente celebra. (Câmara, 1996: 44)

\section{A procura de sentido na projeção de todo o ser através do desenho}

O desenho, para além do registo de um movimento, é o registo de conceitos inter-relacionados. Não existe o desenho sem sentido, porque a sua realização é a procura e o encontro de sentidos. Sem tais desígnios, haveria uma ação sem intencionalidade, ou seja, não aconteceria o desenho. É possível que, quando a destreza adquire uma especial acuidade, o desenhador perca a sua atenção à manualidade - que passará ao domínio da intuição - e se prenda com construção mental fluente: a criatividade. Eis a razão pela qual é indispensável o exercício continuado do desenho, isto é, de adquirir um tal domínio das suas competências que permita, numa fase elevada, a criação livre e consciente segundo uma intencionalidade e eficácia que ultrapasse a inércia física ou incompetências, em que se ultrapassou a procura de sentido na representação formal e se passa a procurar um sentido ao nível espiritual 22 .

Temos em conta nesta análise que o desenho como técnica de representação da forma nos remete para a perícia, sempre que esteja em causa a capacidade de fidelizar a imagem à sua referência. Esta situação coincide com a possibilidade de poder verbalizar o processo de realização de um

22 Espírito designa o conjunto dos processos mentais, principalmente os que relevam da inteligência(...) (Espírito - cf. Doron, R.; Mengal, P.; Richelle, in Roland Doron e Françoise Parot - op. cit., p. 297) 
desenho: cada procedimento tem uma função, cada registo tem uma razão de ser. Mas aqui nós abordamos o desenho como instrumento de concretização de um processo criativo, logo, à perícia acrescentamos a intuição. Isto é, ao sistema deliberado acrescentamos inevitavelmente o sistema tácito. $\mathrm{O}$ primeiro recorre ao pensamento analítico e o segundo ao pensamento sintético. $\mathrm{Na}$ dialéctica entre os dois temos uma complementaridade que promove o encontro de sentido do desenhador-autor.

A ação de desenhar representa-nos a nós próprios na ação de representar, clarifica os itinerários da nossa consciência, tornando-se evidente perante nós próprios. (Molina, 2003:49)

Talvez seja este o sentido que se procura na criação pelo desenho. Contudo, dessa procura não se dissocia a intuição desenvolvida pela imaginação. Trata-se de um desenvolvimento numa condição de intuição total, sem que haja a preocupação da validação. Porém, apesar de a imaginação não nos ligar ao objetivo e ao científico, presta-se a uma produção de pensamento com sentido. A imaginação, mesmo que não faça sentido no contexto real, é produto da procura de sentido. No fundo, a imaginação direciona o nosso pensamento segundo a procura de coerência a partir de um contexto incoerente e inválido na realidade.

As duas realidades perfazem o mental na sua totalidade do desenhador-autor. $\mathrm{O}$ seu funcionamento na plenitude não está, alegadamente, ao nosso alcance, mas podemos desejar tomar essa direção, apesar de para isso termos de ultrapassar barreiras de várias ordens. Daí resulta a evolução do ser. O desejo de evoluir relaciona-se com a necessidade de ultrapassar essas barreiras que impedem a sensação de liberdade.

\section{Expansão da liberdade a partir do alargamento da consciên- cia no contexto do ato de desenhar}

\section{O desenho para um alargamento da realidade}

$\mathrm{O}$ ato de desenhar exige uma atividade corporal que, por sua vez, envolve a atividade da mente, o que parece óbvio. No entanto, deseja-se saber se a ação da mente no ato de desenhar é ou não completamente deliberada e se, nessa dialética corpo-mente, não se proporcionará o fenómeno de consciencialização, na medida em que o desenhador-autor procura um sentido que culmine nesse maior conhecimento de si e do meio.

A vitalidade do ser humano acontece num processo contínuo de trocas de informação que lhe permitem adquirir consciência do mundo. Mas tam- 
bém acontece um processo em que as novas informações interagem com o conhecimento que a sua memória reteve. De tudo isto resulta a possibilidade de formular novas considerações acerca do mundo, além de permitir ao sujeito que se adapte ao mundo (Mendonça, 1998).

O nosso organismo está constantemente a processar informação de várias naturezas, de forma automática e através dos sistemas e subsistemas do interior do nosso corpo, sem que tenhamos consciência desse processamento (Hogarth, 2002). Mas existe informação que não se processa dessa forma automática que é aquela que se processa ao nível consciente (Hogarth, 2002). Sobre esta exercemos uma intencionalidade segundo um sistema deliberado. $\mathrm{O}$ que nos dirige para a asserção de que a consciência implica, necessariamente, um sistema deliberado como resultado de um processo de conhecimento.

O organismo funciona segundo os - referidos por R. Hogarth (2002) sistema deliberativo e sistema tácito. Um e outro condicionam a relação do organismo com o exterior, e é nessa dualidade que a consciência se processa. Um e outro funcionam em termos de informação - permutando informação de várias naturezas, como já foi referido. Ao nível orgânico, a informação gera-se entre as células, ao nível visceral, etc. Se, por um lado, ao nível do organismo, a transmissão de informação é automática, especificamente ao nível mental uma parte dessa transmissão depende da intencionalidade do sujeito. Isto, na medida em que a parte da mente que diz respeito à consciência não funciona aleatoriamente, mas segundo uma vontade que vai para além da ação instintiva do corpo animal.

O Homem tem uma noção retrospetiva (do passado), uma noção reflexiva (do presente ou do passado) e uma noção prospetiva do futuro; temos uma cultura que proporciona valores, uma moral, uma ética e uma noção de liberdade na coexistência dos sujeitos dentro de uma sociedade. Tudo isso proporciona à nossa individualidade um funcionamento que ultrapassa o carácter biológico; existe, também, um funcionamento de caráter social, em que a troca de informação é quase que estrutural. Estes mecanismos de inter-relação (ao nível social) com base numa intra-relação (ao nível individual consciente/inconsciente ${ }^{23}$ ) permitem criar circunstâncias de evolução e progresso que afetam a nossa relação de seres naturais e biológicos com o meio natural e o meio artificial que nós próprios criamos - onde se inclui a própria cultura.

Numa palavra, toda a nossa vida é um processamento de informação ao nível interpessoal e ao nível "intrapessoal". Num e noutro circuito, esse pro-

23 Convém esclarecer que não queremos aqui estabelecer uma dicotomia consciente/inconsciente. $\mathrm{O}$ que de facto é importante aqui sublinhar é que a consciência é um fenómeno que não se pode circunscrever nem concretizar de forma empírica. 
cessamento pode ser emitido ou recebido ao nível da consciência ou da inconsciência. De facto, como nos diz R. Hogarth (2002), os próprios genes "proporcionam informação" que nos nossos corpos permitem ao nosso sistema a regulação do crescimento físico. Podíamos dizer que o fluxo de informação tem o sentido de reequilíbrio constante, de carácter hoemostático.

\section{O desenho no contexto do fluxo de informação}

O desenho, na nossa opinião, não é separável do fluxo de informação, ao nível interno e externo (respetivamente, intrapessoal e interpessoal). Seria essa ordem de devir que constituiria uma necessidade de reequilíbrio entre a informação que é emitida e que é conhecida e a informação que é recebida e desconhecida. Esta última pode ser susceptível de se desejar que se torne consciente. Adquirir consciência do que até determinado momento não se tinha consciência poderá consubstanciar nesse encontro de sentido que cremos que o desenho proporciona.

\section{O desenho: ativador da dialética entre o sistema tácito e o siste- ma deliberado}

Desenhando, agimos sobre a matéria, sobre o visível, sobre o exterior; mas também sobre o imatérico, o invisível e o interior. Esta ação tem como propósitos primordiais o ajustamento do nosso interior e a procura de um sentido, à medida que se vai descobrindo algo de novo interno e externo (ambos, até então, inconscientes). Numa interação entre o exterior, o consciente, o pré-consciente, o inconsciente, procuramos dar sentido àquilo que afeta o nosso comportamento e que não está sob o nosso controlo, mas que pela materialização e pela consciencialização passa a ser suscetível do nosso controlo mental. Na verdade, procuramos ordenar e organizar o nosso interior através da ordenação e organização do nosso exterior, incluindo a informação percetiva sensitiva, a formas bidimensionais e tridimensionais, os seres naturais. A nossa organização mental existe, quando a informação que captamos se compatibiliza com o estado da organização psíquica do momento que experienciamos atualmente. Consideramos que o ato de desenhar o meio, entre outros, facilita este fenómeno.

Numa primeira abordagem, remetendo-nos ao autor R. Hogarth (2002), vamos considerar que qualquer estímulo (seja de natureza interna, por exemplo, um pensamento que provoca outro pensamento; seja de natureza externa, por exemplo, algo que se vê, ouve ou sente), não se dirige diretamente à consciência (Hogarth, 2002). Existe um mediador, o pré-cons- 
ciente, que determina automaticamente se esse estímulo é ou não conduzido para a consciência, ou, por outras palavras, se se torna consciente. Isto é um processo de decisão intuitivo, independentemente de refletir uma tendência inata ou uma tendência apreendida (Hogarth, 2002). Trata-se de um processo ordenador tendo em vista o equilíbrio de caráter orgânico que necessitamos para sobreviver e para conseguirmos nos adaptar ao meio e ao decurso natural do envelhecimento. Mais precisamente, e utilizando as expressões de R. Hogarth (2002), existe uma dialética entre o sistema tácito e o sistema deliberado. Não existe só uma ação do sistema deliberado sobre certos sistemas tácitos, mas pode acontecer o contrário, na perspetiva de R. Hogarth (2002), na medida em que, além do sistema de processamento de informação neural, sensorial e motriz, também o sistema cognitivo, os afetos podem afetar o sistema tácito (Hogarth, 2002). O desenho é, de facto, um mecanismo que implica todas estas realidades num só fenómeno.

O Ser Humano é informação e o meio que o envolve também o é. Temos de considerar que a informação com origem no indivíduo ou no meio, que veicula um conjunto de estímulos que agem sobre a mente, pode ou não tornar-se consciente, na medida em que pode ficar a um nível latente (sem que tenhamos consciência dessa informação), pode impulsionar uma ação (apesar de só termos consciência dela a posteriori) e podem dar lugar a uma ação premeditada (de que se tem consciência a priori) (Hogarth, 2002). No processo criativo pode haver uma oscilação onde se pende ora para a primeira situação, ora para a segunda ou para a terceira. Nesta dinâmica o desenho tem o papel de determinar qual o tipo de pendor predominante.

Portanto, a informação, que é o desenho como sua referência, age sempre sobre a mente, ou segundo um sistema tácito ou segundo um sistema deliberado; mas, em qualquer uma das situações, a informação tanto pode contribuir para o equilíbrio como para o desequilíbrio. Precisamente, a nossa tendência nata para a gestão homeostática, com maior ou menor inteligência (seja de que natureza for), é o que nos vai levar a adotar a informação com um fim utilitário ou recusá-la dada a ameaça ou a inutilidade da mesma.

\section{O desenho como descoberta (da liberdade)}

Com base nessa gestão da informação no fenómeno da consciência, na dialéctica do que é exterior (e ainda não consciente) e do que é interior (que é consciente ou se situa a um nível pré-consciente), tentaremos entender de que forma se processa o fenómeno da consciência no contexto do desenhador-autor. Pois, como nos diz Ana Leonor Rodrigues, "a ideia de desenhar como sendo um vestígio desencadeia imediatamente uma outra constatação da consciência de si através da identificação do Outro" (Rodrigues, 2003: 
68). Logo à partida, esta afirmação remete-nos para a ideia que no processo de gestão de informação, como é o caso do desenho, o indivíduo procura a adaptação ao meio, mas, por sua vez, procura através disto conhecer o que de comum existe entre ele e os indivíduos que compõem parte do meio.

$\mathrm{O}$ desenho-processo permite que o seu autor comunique através da imagem que produz. Mas esta imagem não se dissocia da consciência do autor, uma vez que o corpo, protagonizado pela mão, só produz a imagem como efeito de um processo mental. Daí resultando que o autor tem uma prova de que existe, pois trata-se de um produto da sua mente. Essa prova é o desenho-objeto baseado num referente ${ }^{24}$ a que este reporte, uma memória ou simplesmente algo com origem na imaginação. Quando na sequência da produção do desenho-objeto a consciência do autor sofra uma modificação. Ou, melhor, que se torne mais alargada (Damásio, 2004), e, por consequência, mais adaptável ao meio, na medida em que conhece maior diversidade de informação que compõe o universo (humano, animal, físico, químico, etc.).

Ao observarmos o processo de desenho, percebemos diretamente a informação dos registos que traduzem o efeito da nossa mente sobre o nosso corpo. Conseguimos tal proeza, porque existiu uma inter-aprendizagem, existiu um mercado de informação que nos permitiu aproximarmo-nos do estágio de equilíbrio, no contexto da Natureza de que fazemos parte, em que o que nos é exterior não é uma ameaça; é, sim, uma ligação do indivíduo aos outros indivíduos, gerando o coletivo, ou melhor, o universal.

Não se pode, contudo, confundir tradução do desenho somente com o processo da consciência, pois a mente é um sistema onde se incluem também conteúdos inconscientes. Mas o universal é uno, e o consciente e o inconsciente fazem parte dum todo indiferenciadamente vital para o Ser Humano. Os próprios registos podem ter sido o efeito de conteúdos de que não somos conscientes. A consciência pode atingir níveis mais elevados da mente, como poderemos verificar mais à frente. O que pretende o Ser Humano é procurar a sua liberdade, sendo que esta existe quando se atingir o máximo da consciência, coisa que não está ao nosso alcance, por esse motivo nunca nos sentimos total e definitivamente livres.

Parte-se da premissa, então, de que o desenho se pratica enquanto meio de procura da liberdade. Sendo um processo que acontece ao nível mental e que se concretiza através da motorização do nosso corpo, talvez não se possa enquadrar numa lógico-dedutiva, pois, diz-nos J. Molina, que o desenho permite um percurso de descoberta em que "o representar o inefável

24 Referente "é o termo usado por alguns linguistas para designar o tipo de seres ou objectos para os quais remete uma palavra na realidade" (cf. Clément, 1999: 330). Nós extrapolamos este significado, assumindo-o como o tipo de objetos ou seres para os quais remete um desenho. 
ou penetrar no caminho insondável do eu mais íntimo obriga a caminhar no território das revelações; submeter-se a imagens que não podem ser deduzidas mas sim descobertas" (Molina: 2003: 50). A dedução, de certa forma, pode fechar, por se tratar de um logicismo; portanto, é necessário que a imaginação, que abre, se acople à lógica.

Desenho é a procura da descoberta (da liberdade). Sugeríamos, então, que o desenho permite descobrir o que de inconsciente ou latente se vai produzindo na nossa mente, mas também o que os nossos sentidos captam do mundo, que quando submetidos ao processo de consciência passam a estar descobertos do manto da inexistência. Associar-se-ia o desenho, nesta medida, a um processo indutivo, em que se fazem inferências conjeturais da realidade que se vê, em que se parte do particular para o geral, mas num sentido em que a descoberta não é definitiva nem determinada. Abertura é universalizar. Procura-se, assim, alargar a consciência do/sobre o Mundo, em direcção ao universal: percurso infinito. Uns procuram esse infinito no Desenho, outros na dança, outros na música. Quem pratica a arte procura uma felicidade espiritual, aquela que na realidade ultrapassa o material (possível de circunscrever), o universal (impossível de circunscrever). A felicidade é, numa palavra, aquele(s) momento(s) em que sentimos o universo, em que toda a informação de que temos alcance se equilibra, em que a homeostasia, por momentos, atinge um estádio culminante, de satisfação total de todas as necessidades do organismo.

Para que o sujeito tenha consciência do não-eu (toda a informação de que ainda não tem consciência e que lhe é exterior), para que o descubra, ter-se-ia de criar uma distância entre o conhecido e o desconhecido, isto é, permitir que o sujeito se separe do mundo reduzido, quando o indivíduo se isola, e se aproxime do mundo expandido, quando o indivíduo se partilha. E a mediação entre o indivíduo e o mundo, mais do que ser feita através da linguagem, sê-lo-ia com recurso às analogias, em que se procuram pontes entre o que é distante, (mais do que pelo pensamento convergente) pelo pensamento divergente.

Ter consciência do / ou descobrir o não-eu implicará que nos distanciemos dele, pois se tal não acontece, se estivermos diluídos nele, a subjetividade sobrepor-se-á à objetividade. O que não se deseja, pois tem de haver um equilíbrio entre estes dois pólos.

No sentido de que o cérebro veja de uma forma menos subjetiva, o desenho poderá ser trabalhado para "mobilizar a mente e «ensinar» o cérebro a ver e utilizar essa capacidade de modos específicos e úteis a uma área vasta de ações" (Rodrigues, 2003: 10). Portanto, para mergulhar no universo, temos de nos distanciar da nossa subjetividade individual, procurando compreender a individualidade dos outros seres; é a sua diversidade que nos facultará a compreensão do universo em que habitamos, ou que nos habita. 


\section{A transformação da consciência através do desenho-processo (o conhecido e o ainda não conhecido)}

A transformação da consciência é o produto de modificações norteadas pela mente, em que existe, reiteramos, um permanente diálogo do interno com o externo, do ainda não incorporado com o já incorporado, do inconsciente com o consciente; onde se pode incluir o desenho para a criação como um dos grandes agentes transformadores da consciência.

Parar de se ser crítico na atividade do desenho criativo resultaria num produto folclórico e sem inovação, pois de nada serviria no processo de alargamento da consciência; apenas daria a ilusória felicidade ao "autor" dada a segurança que lhe daria a rotina reprodutora da imagem (o que acontece em qualquer tipo de atividade reprodutora, incluindo o artesanato). Mais, deixar-nos-íamos conduzir pelo instinto e menos pela liberdade da razão. Não é concebível, portanto, que um desenhador-autor se prive de um permanente juízo crítico, sob pena de, num extremo, produzir um desenho esquizofrénico. Para que isso não aconteça, supomos haver a necessidade de que o desenhador-autor siga uma intensa procura do conhecimento (de si), dos seus afetos, para poder interagir com o Outro através de uma inter-partilha de afeto. Um percurso que se orienta pela aproximação aos bons afetos, tentando perceber o que nos distancia deles e nos impede de ser livres de ser afetuosos. A resignação com o que o indivíduo conhece (de si), sem querer evoluir, seria um fator de estagnação na escalada da liberdade. Sugerimos que o desenho só existe se, a cada momento, se combater essa estagnação, questionando sempre o adquirido, e se o desenho tiver como fim a transformação da consciência do autor, em que, compreendendo a razão dos maus afetos, expande o sentido livre de existência. O que é possível sempre que transpusermos as fronteiras que vão aparecendo (que muitas vezes se auto-repõem). Procura-se, por isso, no desenho, quebrar constantes barreiras que limitam as fronteiras entre o adquirido e o que se deseja adquirir, entre a segurança do que se conhece e a insegurança do que ainda não se conhece.

O desenho de representação induz um observador leigo a uma sua receção interpretando-o tendo como uma referência que normalmente tem a ver com o conhecido. Em contrapartida, o trabalho que o desenhador-autor faz no sentido de uma interrogação exige uma pesquisa interior, com maior profundidade, do que é em si desconhecido, transportando o observador para uma inquietação. A diferença coloca-se na grandeza da luta contra as barreiras que se interpõem, conforme a fronteira separe uma realidade mais ou menos profunda (mais ou menos inconsciente) No âmbito da criação pelo desenho, as vias de condução a esse fim remetem-nos para a produção artística e para a perceção e pensamento (Molina, 2003). Nessa relação dinâmica entre o conhecido e o que se quer conhecer, ao nível interno e externo, exis- 
tem esses processos (a produção artística, a perceção e o pensamento) que interatuam, influenciando-se reciprocamente. A liberdade conquista-se no contexto sistémico. Portanto, não faz sentido compartimentar áreas de fenómeno; é mais correto dizer que todas interatuam inevitavelmente e em siste$\mathrm{ma}(\mathrm{s})$.

Como nos diz Copón (2003: 430), "a perceção não é objetiva nem ingénua, opera mediante interesses, afinidades, ressonâncias entre o percebido e o [perceptor]" e, acrescenta mais à frente, "neste sistema de separação, que funda o conhecimento como desejo, estabelece-se, por sua vez, uma correlação entre as aparências que damos ao real com o autoconhecimento das nossas possibilidades internas". Estas ideias permitem-nos confluir no sentido de que o saber-ser ${ }^{25}$ (que se adquire com a experiência de vida, mas que pensamos ter como fator importante da criação) será o resultado da dialéctica entre o pensamento, a perceção e a criação (artística), que são realidades com que o desenho trabalha quando utilizado para criar. Mais precisamente, o saber-ser será a elevação progressiva do indivíduo desenvolver os alicerces que potenciam a expansão da sua liberdade num todo sistémico e holístico.

O desenho inclui todos os tipos de saber - saber, saber-fazer e saber-ser -, sem os quais não o é na totalidade, pois ele mobiliza "todos os sistemas de relação que usamos para existir, com uma ênfase particular na observação e nos afetos" (Rodrigues, 2003: 70-71). Por essa razão, não dissociamos o desenho do âmbito da criação, pois esta atividade mobiliza outras competências, outros níveis da consciência, que a mera tradução do real talvez não mobilize (apesar de ambas implicarem os afetos).

$\mathrm{O}$ desenho é saber, pois exige uma aprendizagem onde se requer saber comparar proporções, definir volumes (são noções que, apesar de não serem necessariamente explicadas segundo teorias científicas, são explicáveis de forma lógica); ele é saber-fazer, pois é preciso saber traduzir esses dados graficamente; ele é, por fim, saber-ser, pois implica que o desenhador seja autor, e para ser autor tem de transmitir a sua idiossincrasia e a sua capacidade de ser livre das amarras do instinto, do inconsciente e do desconhecido; tem de, numa palavra, traduzir a sua conquista de uma parcela de maior consciência (de si e do mundo). Supondo que a consciência é o resultado da conjugação dos diferentes saberes, o desenho poderá bem ser um meio que, ativando, também, os mesmos saberes em conjunto, poderá contribuir para o fenómeno da consciência, no sentido de transformar o indivíduo num ser mais livre.

25 O saber ser é aqui entendido como uma qualidade de ter uma consciência mais alargada de si próprio integradamente no meio de que terá também uma consciência tendencialmente maior. 


\section{Referências}

Câmara, J. B. (2005). Expressão e Contemporaneidade: A arte moderna segundo Merleau-Ponty. Lisboa: Imprensa Nacional-Casa da Moeda.

Copón, M. (2005). Las palabras del dibujo: sobre el pensar gráfico. In J. Molina, L. Cabezas, M. Copón, Los Nombres del Dibujo (pp. 447-572). Madrid: Ediciones Cátedra.

Copón, M. (2003). Conocimiento como naturaleza muerta. In J. Molina (coord.). Las Lecciones del Dibujo ( $3^{\text {a }}$ edición, pp. 429-452). Madrid: Ediciones Cátedra.

Costa, J., \& Melo, A. (1998). Dicionário da Língua Portuguesa (8 a edição). Porto: Porto Editora.

Damásio, A. (2004). O Sentimento de Si: O corpo, a emoção e a neurobiologia da consciência (15 a edição). Mem Martins: Publicações Europa América.

Doron, R., \& Parot, F. (Dir.) (2001). Dicionário de Psicologia (1 ${ }^{\mathrm{a}}$ edição). Lisboa: Climepsi Editores.

Hogarth, R. (2002). Educar la Intuición: El desarrollo del sexto sentido. Barcelona: Editorial Paidós Ibérica.

Khan, P., Clément, E., Demonque, C., \& Hansen-Love, L. (1999). Dicionário Prático de Filosofia ( $2^{\mathrm{a}}$ edição). Lisboa: Terramar.

Malrieu, P. (D. L. 1996). A Construção do Imaginário. Lisboa: Instituto Piaget.

Mendonça, J-L. (1998). Cérebro esquerdo, cérebro direito. Lisboa: Instituto Piaget.

Mereau-Ponty, M. (2004). O Olho e o espírito ( $5^{\mathrm{a}}$ edição). Sacavém: Vega.

Molina, J. (2005). Las palabras y los nombres. In J. Molina, L. Cabezas, M. Copón, Los Nombres del Dibujo (1 ${ }^{\mathrm{a}}$ edición, pp. 11-74). Madrid: Ediciones Cátedra.

Molina, J. (2005). Radiografía de un viaje. In J. Molina, L. Cabezas, M. Copón, Los Nombres del Dibujo ( $1^{\text {a }}$ edición, pp. 75-219). Madrid: Ediciones Cátedra.

Molina, J. (2003). El concepto de dibujo. In J. Molina (coord.). Las Lecciones del Dibujo ( $3^{\mathrm{a}}$ edición, pp. 17-167). Madrid: Ediciónes Cátedra.

Rodrigues, A. (2003). O que é Desenho (1 ${ }^{\text {a }}$ edição). [S. 1.]: Quimera.

Rodrigues, A. (2000). O Desenho: Ordem do Pensamento Arquitectónico (1 ${ }^{\mathrm{a}}$ edição). Lisboa: Editorial Estampa.

Rodrigues, L. (2010). Desenho, Criação e Consciência (1ª edição). Lisboa: Bond Editora. 